p-ISSN 261 5-286X | e-ISSN 2798-5075

DOI 1052646

\title{
GAMBARAN PERAN KELUARGA DALAM MERAWAT PASIEN GANGGUAN JIWA SKIZOFRENIA YANG MENGALAMI KEKAMBUHANDI INSTALASI RAWAT JALAN RUMAH SAKIT JIWA DAERAH ABEPURA
}

\author{
Haslinda Manda ${ }^{1}$, Rifki Sakinah Nompo ${ }^{2}$, Muh. Rhomandoni ${ }^{3}$ \\ ${ }^{1}$ Rumah Sakit Jiwa Daerah Abepura - Jayapura \\ ${ }^{2}$ Prodi Pendidikan Profesi Ners STIKES Jayapura \\ Email: rifkisakinahnompo@gmail.com
}

\begin{abstract}
ABSTRAK
Latar Belakang: Skizofrenia merupakan penyakit mental yang serius. Penyakit ini disebabkan oleh gangguan konsentrasi neurotransmiter otak, perubahan reseptor sel-sel otak, dan kelainan otak struktural. Pasien akan memiliki pemikiran, perasaan, emosi, ucapan, dan perilaku yang tidak normal, yang memengaruhi kehidupan, pekerjaan, kegiatan sosial, dan kemampuan untuk mengurus diri mereka sehari-hari sehingga mereka membutuhkan keluarga dalam membantu proses pemulihan selama berada di rumah. Peran keluarga merupakan pendukung penting dalam proses pemulihan pasien skizofrenia terutama untuk mencegah terjadinya kekambuhan. Sikap keluarga yang tidak menerima pasien skizofrenia atau bersikap bermusuhan dengan pasien akan membuat kekambuhan terjadi. Tujuan: mengidentifikasi gambaran peran keluarga dalam merawat pasien gangguan jiwa skizofrenia yang mengalami kekambuhan di Rumah Sakit Jiwa Abepura. Metode Penelitian: menggunakan deskriptif kuantitatif, dengan jumlah sampel 30 responden, serta analisa data menggunakan prosentase. Hasil: dari 30 responden yang diteliti 15 keluarga (50.0\%) berperan dalam merawat kekambuhan pasien skizofrenia dan 15 keluarga (50.0\%) tidak berperan dalam merawat kekambuhan pasien skizofrenia. Kesimpulan: penelitian menunjukkan hasil seimbang antara keluarga yang berperan dalam merawat kekambuhan pasien skizofrenia, hal ini mungkin terjadi karena kurangnya informasi atau pengetahuan mengenai perawatan pasien skizofrenia di rumah, dan stigma yang masih melekat pada masyarakat seperti: dikucilkan, tidak dapat berproduktifitas, tidak berguna, menakutkan, dan lain sebagainya.
\end{abstract}

Kata Kunci: Peran Keluarga, Skizofrenia, Kekambuhan

\begin{abstract}
Background: Schizophrenia is a serious mental illness. This disease is caused by impaired concentration of brain neurotransmitters, changes in brain cell receptors, and structural brain abnormalities. Patients will have thoughts, feelings, emotions, speech, and behavior that are not normal, which affect life, work, social activities, and the ability to take care of themselves daily so that they need their family to help with the recovery process while at home. The role of the family is an important supporter in the recovery process for schizophrenia patients, especially to prevent relapses. The family attitude that does not accept schizophrenic patients or is hostile towards the patient will make relapses occur. Objective: to identify the description of the role of the family in caring for schizophrenic mental patients who experience recurrence at Abepura Mental Hospital. Research methods: using quantitative descriptive, with a sample size of 30 respondents, and data analysis using percentages. Results: Of the 30 respondents studied, 15 families (50.0\%) played a role in treating recurrence of schizophrenia patients and 15 families (50.0\%) had no role in treating recurrence of schizophrenia patients. Conclusion: the study shows balanced results between families who play a role in treating recurrence of schizophrenic patients, this may occur due to a lack of information or knowledge about the care of schizophrenic patients at home, and the stigma that is still attached to society such as: being excluded, unable to produce, useless, scary, and so on.
\end{abstract}

Keywords: Role of Family, Schizophrenia, Recurrence 


\section{PENDAHULUAN}

Skizofrenia merupakan kelainan psikis yang menempati peringkat kedua setelah penyakit jantung (Jested \& Mueser, 2011). Skizofrenia memerlukan perawatan dengan jangka waktu yang lama terutama dalam pengobatan, diperburuk dengan tingginya angka kekambuhan pada pasien. Angka kekambuhan berhubungan dengan seberapa kali masuk rumah sakit jiwa, lamanya proses pengobatan dan perjalanan penyakit.

Menurut World Health Organization (WHO, 2010) penderita gangguan psikis dengan diagnosa skizofrenia telah menjangkit kurang lebih 24 juta jiwa di seluruh dunia. Data dari American Psychiatric Assosition (APA) pada tahun 2009, prevalensi skizofrenia di Indonesia sekitar $1 \%$ dari seluruh penduduk di dunia. Prevalensi penderita skizofrenia di Indonesia sendiri adalah $0,3 \%-1 \%$ dan biasanya timbul pada usia sekitar 15-45 Tahun, sedangkan dari beberapa sumber lain menyebutkan uji skizofrenia timbul pada saat berusia 11-12 Tahun sudah menderita skizofrenia. Sekitar 99\% pasien rumah sakit jiwa di Indonesia merupakan penderita skizofrenia (Arif, 2011).

Hasil penelitian Porkony et al., (2012) menyatakan bahwa $49 \%$ pasien skizofrenia mengalami rawat ulang setelah follow up selama satu tahun, sedangkan pasien-pasien non skizofrenia hanya $28 \%$ penelitian serupa yang dilakukan oleh Salomon et al., (2012), menyatakan bahwa dalam waktu 6 bulan pascarawat didapat $30 \%-40 \%$ penderita banyak mengalami kekambuhan. Tingkat kekambuhan sering diukur dengan menilai waktu antara lepas rawat dari perawatan terakhir sampai perawatan berikutnya dan jumlah rawat inap pada periode tertentu (Pratt, 2011).

Penelitian dengan metode kuantitatif dilakukan pada sebuah keluarga di Amerika membutikan bahwa peran keluarga yang baik dapat mengurangi angka perawatan di rumah sakit, kekambuhan, dan memperpanjang waktu antara kekambuhan (Geddes, 2008; Lauriello, 2015). Menurut Sullinger (2010) pasien dengan diagnosa skizofrenia diperkirakan akan mengalami kekambuhan $50 \%$ pada tahun pertama, $70 \%$ pada tahun ke dua dan $100 \%$ pada tahun ke lima setelah pulang dari Rumah Sakit, hal ini berhubungandengan perlakuan pasien selama berada di rumah atau di masyarakat (Arif, 2010).

Hasil penelitian menurut (Sullinger, 2010) terdapat $25 \%-50 \%$ pasien yang pulang dari rumah sakit jiwa tidak meminum obatnya secara teratur, hal inilah yang sering menyebabkan kekambuhan atau relaps pada pasien gangguan jiwa, salah satu penyebab pasien skizofrenia tidak teratur memakan obat adalah karena kurangnya peran serta keluarga dalam perawatan anggota keluarga yang menderita penyakit skizofrenia. Menurut Keliat (2012) ada beberapa faktor yang dapat mempengaruhi kekambuhan yaitu pasien, dokter, penanggung jawab pasien (perawat) dan keluarga.

Terdapat dua jenis peran dalam keluarga yaitu peran formal dan peran informal, peran formal sendiri merupakan peran yang sudah jelas dan nyata terlihat seperti peran suami/ayah, istri ibu, anak, kakak - adik. Peran informal peran secara tertutup, bersifat implisit, seringkali tidak tampak pada permukaannya, dan di harapakan memenuhi emosional keluarga dan atau memelihara keseimbangan keluarga (Satir, 2012).

Keluarga memainkan suatu peran yang bersifat mendukung selama penyembuhan dan pemulihan pasien skizofrenia, apabila dukungan semacam ini tidak ada, maka keberhasilan penyembuhan atau pemulihan (rehabilitas) berkurang, hal ini dapat berdampak buruk bagi pasien dan anggota keluarga (Friedman, 2010).

Dari hasil pengambilan awal di Rumah Sakit Jiwa Daerah Abepura memiliki kunjungan pasien baru dan pasien lama yang cukup tinggi di instalasi rawat jalan maupun rawat inap. Khususnya pada instalasi rawat jalan tahun 2017 terdapat 6.007 pasien rawat jalan dengan jumlah pasien pasien lama sebanyak 5.737 (96\%) dan baru sebanyak 270 (4\%), jumlah kunjungan skizofrenia sebanyak 4.363 pada tahun 2017. Jumlah kunjungan pasien dengan kekambuhan cenderung meningkat yang seharusnya pasien tidak perlu dirawat namun harus menjalani perawatan ulang (rawat inap) karena kambuh di rumah sakit jiwa.

Dari hasil wawancara pada perawat yang bekerja di unit rawat jalan, mengatakan bahwa setiap hari jumlah pasien dengan gangguan jiwa yang datang berobat tidak sedikit, jumlahnya beragam dari yang baru rawat inap dan datang untuk kontrol. Pasien yang biasanya datang di temani oleh keluarga ialah pasien yang sebelumnya sudah sembuh namun kembali karena terjadi kekambuhan, hal ini dapat disebabkan karena kurangnya peran keluarga di rumah, mereka beranggapan jika anggota keluarga mereka sudah dapat menjalankan kehidupan sehari- 
harinya denga normal, pasien tidak perlu minum obat kembali atau putus kontrol.

Hasil wawancara yang dilakukan kepada tiga keluarga yang mengantar anggota keluarga dengan gangguan jiwa skizofrenia untuk berobat ke instalasi rawat jalan, dua keluarga mengatakan bahwa mereka hanya bersikap pasrah dirumah, mereka tahu dan menyadari jika anggota keluarganya ada yang mengalami gangguan jiwa, pasien jarang dilibatkan dala kegiatan rumah, pasien hanya menghabiskan hari-harinya dikamar kemudian satu keluarga juga mengatakan bahwa mereka tahu dan menyadari jika memiliki anggota keluarga yang sakit dan mereka sudah melibatkan pasien dalam kegiatan dirumah tapi tetap saja terjadi kekambuhan.

Dari penuturan para keluarga didapatkan bahwa pasien setidaknya pernah dirawat dua kali dalam satu tahun terakhir, sehingga keluarga merasa kesal dan bosan setiap pasien melakukan tingkah laku yang aneh, padahal dahulu sudah dinyatakan sembuh atau kondisinya sudah membaik oleh dokter, sekarang malah harus berobat kembali karena pasien mengalami kekambuhan.

Berdasarkan latar belakang yang telah diuraikan diatas tersebut, peneliti sangat tertarik melakukan penelitian untuk mengetahui gambaran peran keluarga dengan pasien skizofrenia yang mengalami kekambuhan.Judul penelitian ini adalah Gambaran Peran Keluarga dalam Merawat Pasien Gangguan Jiwa Skizofrenia yang Mengalami Kekambuhan di Instalasi Rawat Jalan Rumah Sakit Jiwa Daerah Abepura.

\section{METODE PENELITIAN}

Analisa yang digunakan dalam penelitian ini adalah analisa univariat adalah analisis yang dilakukan untuk menjelaskan karakteristik responden keluarga (usia, jenis kelamin, pendidikan, pekerjaan, status pernikahan, hubungan dengan pasien), karakteristik pasien skizofrenia (usia, lama menderita skizofrenia, kekambuhan, jumlah rawat di RSJ, terakhir dirawat di RSJ), dan peran keluarga dalam merawat pasien gangguan jiwa skizofrenia yang mengalami kekambuhan. penelitian dilakukan di Instalasi Rawat Jalan Rumah Sakit Jiwa Daerah Abepura pada bulan Juni hingga Agustus 2018.

\section{HASIL PENELITIAN}

Hasil penelitian ini menggunakan analisa univariat, dimana peneliti akan memaparkan mengenai karakteristik responden keluarga (usia, jenis kelamin, pendidikan, pekerjaan, status pernikahan, hubungan dengan pasien), karakteristik pasien skizofrenia (usia, lama menderita skizofrenia, kekambuhan, jumlah rawat di RSJ, terakhir dirawat di RSJ), dan peran keluarga dalam merawat pasien gangguan jiwa skizofrenia yang mengalami kekambuhan.

Tabel 1 Karakteristik Responden Keluarga

\begin{tabular}{|c|c|c|}
\hline Karakteristik & Frekuensi & $\%$ \\
\hline \multicolumn{3}{|l|}{ Usia } \\
\hline 17-25 tahun & 13 & 43.3 \\
\hline 26-35 tahun & 7 & 23.3 \\
\hline 36-45 tahun & 2 & 6.7 \\
\hline 46-55 tahun & 3 & 10.0 \\
\hline 56-65 tahun & 5 & 16.7 \\
\hline Total & 30 & 100.0 \\
\hline \multicolumn{3}{|l|}{ Jenis Kelamin } \\
\hline Laki-laki & 18 & 60.0 \\
\hline Perempuan & 12 & 40.0 \\
\hline Total & 30 & 100.0 \\
\hline \multicolumn{3}{|l|}{ Pendidikan } \\
\hline SD & 6 & 20.0 \\
\hline SLTP & 1 & 3.3 \\
\hline SLTA & 15 & 50.0 \\
\hline Sarjana & 8 & 26.7 \\
\hline Total & 30 & 100.0 \\
\hline \multicolumn{3}{|l|}{ Pekerjaan } \\
\hline PNS & 6 & 20.0 \\
\hline Karyawan & 1 & 3.3 \\
\hline Wiraswasta & 8 & 26.7 \\
\hline Buruh & 1 & 3.3 \\
\hline Petani & 14 & 46.7 \\
\hline Total & 30 & 100.0 \\
\hline \multicolumn{3}{|l|}{ Status Pernikahan } \\
\hline Belum menikah & 15 & 50.0 \\
\hline Menikah & 14 & 46.7 \\
\hline Duda/Janda & 1 & 3.3 \\
\hline Total & 30 & 100.0 \\
\hline \multicolumn{3}{|c|}{ Hubungan dengan Pasien } \\
\hline Ayah & 4 & 13.3 \\
\hline Ibu & 2 & 6.7 \\
\hline Anak & 7 & 23.3 \\
\hline Suami/Istri & 2 & 6.7 \\
\hline Kakak/Adik & 15 & 50.0 \\
\hline Total & 30 & 100.0 \\
\hline
\end{tabular}


Haslinda Manda : Gambaran Peran Keluarga Dalam Merawat Pasien Gangguan Jiwa Skizofrenia Yang Mengalami Kekambuhandi Instalasi Rawat Jalan Rumah Sakit Jiwa Daerah Abepura

Pada tabel 1 pengelompokan usia diurutkan berdasarkan Departemen Kesehatan tahun 2009. Dari 30 respoden yang diteliti, 13 orang atau 43.4\% diantaranya berusia 17-25 tahun, 7 orang atau $23.3 \%$ diantaranya berusia 26-35 tahun, 2 orang atau $6.7 \%$ diantaranya berusia 36-45 tahun, 3 orang atau $10.0 \%$ diantaranya berusia $46-55$ tahun dan 5 orang atau $16.7 \%$ diantaranya berusia 56-65 tahun. Hal ini menunjukkan bahwa sebagian besar responden berusia antara 17-25 tahun dan minoritas berusia 36-45 tahun.

Karakteristik responden berdasarkan jenis kelamin. Dari 30 responden yang diteliti, 18 orang atau $60.0 \%$ diantaranya berjenis kelamin laki-laki dan 12 orang atau $40.0 \%$ diantaranya berjenis kelamin perempuan. Hal ini menunjukkan bahwa mayoritas responden berjenis kelamin laki-laki.

Karakteristik responden berdasarkan tingkat pendidikan. Dari 30 responden yang diteliti, 6 orang atau $20.0 \%$ diantaranya berpendidikan SD, 1 orang atau $3.3 \%$ diantaranya berpendidikan SLTP, 15 orang atau $50.0 \%$ diantaranya berpendidikan SLTA dan 8 orang atau $26.7 \%$ diantaranya berpendidikan Sarjana. Hal ini menunjukkan bahwa sebagian besar responden berpendidikan SLTA dan minoritas berpendidikan SLTP.

Karakteristik responden berdasarkan pekerjaan. Dari 30 responden yang diteliti, 6 orang atau $20.0 \%$ diantaranya bekerja sebagai PNS, 1 orang atau $3.3 \%$ diantaranya bekerja sebagai karyawan, 8 orang atau $26.7 \%$ diantaranya bekerja sebagai wiraswasta, 1 orang atau $3.3 \%$ diantaranya bekerja sebagai buruh dan 14 orang atau $46.7 \%$ diantaranya bekerja sebagai Petani. Hal ini menunjukkan bahwa sebagian besar responden bekerja sebagai seorang Petani.

Karakteristik responden berdasarkan status pernikahan. Dari 30 responden yang diteliti, 15 orang atau $50.0 \%$ diantaranya belum menikah, 14 orang atau $46.7 \%$ diantaranya menikah dan 1 orang atau $3.3 \%$ diantaranya duda/janda. Hal ini menunjukkan bahwa mayoritas responden berstatus belum menikah.

Karakteristik responden berdasarkan hubungan dengan pasien skizofrenia. Dari 30 responden yang diteliti, 4 orang atau $13.3 \%$ diantaranya berperan sebagai ayah, 2 orang atau

$6.7 \%$ diantaranya berperan sebagai ibu, 7 orang atau $23.3 \%$ diantaranya berperan sebagai anak, 2 orang atau $6.7 \%$ diantaranya berperan sebagai suami/istri, 15 orang atau $50.0 \%$ diantaranya berperan sebagai Kakak/Adik. Hal ini menunjukkan bahwa mayoritas pasien skizofrenia di bawa ke rumah sakit oleh kakak/adiknya.

Tabel 2 Karakteristik Pasien Skizofrenia

\begin{tabular}{lcc}
\hline \multicolumn{1}{c}{ Karakteristik } & Frekuensi & \% \\
\hline Usia & & \\
17-25 tahun & 6 & 20.0 \\
26-35 tahun & 14 & 46.7 \\
36-45 tahun & 4 & 13.3 \\
46-55 tahun & 3 & 10.0 \\
56-65 tahun & 3 & 10.0 \\
Total & 30 & 100.0 \\
\hline Lama menderita Skizofrenia & & \\
1-5 tahun & 26 & 86.7 \\
6-10 tahun & 3 & 10.0 \\
11-15 tahun & 1 & 3.3 \\
Total & 30 & 100.0 \\
\hline Sering kambuh & & \\
Ya & 17 & 56.7 \\
Tidak & 13 & 43.3 \\
Total & 30 & 100.0 \\
\hline Jumlah Rawat Inap di RSJ & & \\
Tidak pernah & 1 & 3.3 \\
1-5 kali & 25 & 83.3 \\
6-10 kali & 3 & 10.0 \\
11-15 kali & 1 & 3.3 \\
Total & 30 & 100.0 \\
\hline Terakhir dirawat di RSJ & & \\
1-6 bulan & & \\
7-12 bulan & & 60.0 \\
19-24 bulan & & 33.0 \\
Total & & 6.7 \\
& & 100.0 \\
\hline
\end{tabular}

Pada tabel 2 pengelompokan usia pasien skizofrenia diurutkan berdasarkan Departemen Kesehatan tahun 2009. Dari 30 pasien, 6 orang atau $20.0 \%$ diantaranya berusia 17-25 tahun, 14 orang atau $46.7 \%$ diantaranya berusia 26-35 tahun, 4 orang atau $13.3 \%$ diantaranya berusia $36-$ 45 tahun, 3 orang atau $10.0 \%$ diantaranya berusia 46-55 tahun dan 3 orang atau $10.0 \%$ diantaranya berusia 56-65 tahun. Hal ini menunjukkan bahwa sebagian besar pasien skizofrenia berusia antara 26-35 tahun.

Karakteristik pasien berdasarkan lama menderita penyakit skizofrenia. Dari 30 pasien, 26 orang atau $86.7 \%$ diantaranya lama menderita skizofrenia 1-5 tahun, 3 orang atau $10.0 \%$ diantaranya lama menderita skizofrenia 6-10 tahun dan 1 orang atau $3.3 \%$ diantaranya lama menderita skizofrenia 11-15 tahun. Hal ini menunjukkan bahwa sebagian besar pasien menderita skizofrenia 1-5 tahun. 
Karakteristik pasien berdasarkan kekambuhan skizofrenia. Dari 30 pasien, 17 orang atau $56.7 \%$ diantaranya sering mengalami kekambuhan dan 13 orang atau $43.3 \%$ diantaranya tidak mengalami kekambuhan. Hal ini menunjukkan bahwa sebagian besar pasien pernah mengalami kekambuhan skizofrenia.

Karakteristik pasien berdasarkan jumlah rawat di Rumah Sakit Jiwa. Dari 30 pasien, 1 orang atau $3.3 \%$ diantaranya tidak pernah dirawat di RSJ, 25 orang atau $83.3 \%$ diantaranya 1-5 kali dirawat di RSJ, 3 orang atau $10.0 \%$ diantaranya 610 kali dirawat di RSJ dan 1 orang atau 3.3\% diantaranya 11-15 kali dirawat di RSJ. Hal ini menunjukkan bahwa sebagian besar pasien dirawat di RSJ sebanyak 1-5 kali.

Karakteristik pasien berdasarkan terakhir dirawat di RSJ. Dari 30 pasien skizofrenia, 18 orang atau $60.0 \%$ diantaranya dirawat di RSJ 1-6 bulan terakhir, 10 orang atau $33.0 \%$ diantaranya dirawat di RSJ 7-12 bulan terakhir, 2 orang atau $6.7 \%$ diantaranya dirawat di RSJ 19-24 bulan terakhir. Hal ini menunjukkan bahwa sebagian responden dirawat sekitar 1-6 bulan terakhir.

Tabel 3 Peran Keluarga Dalam Merawat Pasien Skizofrenia yang Mengalami Kekambuhan

\begin{tabular}{ccc}
\hline Kategori & Frekuensi & \% \\
\hline Peran Keluarga & & \\
Berperan & 15 & 50.0 \\
Tidak berperan & 15 & 50.0 \\
Total & 31 & 100.0 \\
\hline
\end{tabular}

Pada tabel 3 menggambarkan peran keluarga dalam merawat pasien gangguan jiwa skizofrenia yang mengalami kekambuhan. Dari 30 responden yang diteliti 15 keluarga atau 50.0\% diantaranya berperan dalam merawat kekambuhan pasien dan 15 keluarga atau $50.0 \%$ tidak berperan dalam merawat kekambuhan pasien. Hal ini menunjukkan bahwa sebanding antara keluarga yang berperan dalam merawat kekambuhan pasien skizofrenia dan keluarga yang tidak berperan dalam merawat kekambuhan pasien skizofrenia.

\section{PEMBAHASAN}

Keluarga sebagai pemberi perawatan utama atau caregiver mengambil keputusan terhadap pengobatan dengan membawa pasien berobat ke Rumah Sakit upaya penyembuhan sehingga pasien dapat terhindar dari dampak maupun komplikasi yang akan timbul. Selain itu, keluarga juga sebagai orang terdekat yang dapat membantu memenuhi kebutuhan sehari-hari kepada anggota keluarga yang sakit.

Peran diartikan sebagai kemampuan untuk mempengaruhi atau mengubah perilaku orang lain (Supartini, 2014). Peranan keluarga mengembangkan seperangkat perilaku antar pribadi, sifat, kegiatan yang berhubungan dengan pribadi dalam posisi dan situasi tertentu (Setiadi, 2015).

Pentingnya peran keluarga dalam upaya kesembuhan pasien dikarenakan keluarga merupakan sistem pendukung utama yang memberikan perawatan langsung pada setiap keadaan sehat dan sakit. Keluarga merupakan unit paling dekat dengan penderita dan merupakan "perawat utama" bagi penderita. Keluarga berperan dalam menentukan cara atau perawatan yang diperlukan penderita di rumah. Keberhasilan perawat di rumah sakit akan sia-sia jika tidak di teruskan di rumah yang kemudian mengakibatkan penderita harus dirawat kembali (kambuh). Peran serta keluarga sejak awal perawatan di rumah sakit akan meningkatkan kemampuan keluarga merawat penderita di rumah sehingga kemungkinan kambuh dapat dicegah (Keliat, 2000 dalam Nasir, 2012).

Menurut Keliat (2010) ada beberapa faktor yang dapat mempengaruhi kekambuhan atau relaps pasien skizofrenia yaitu pasien, dokter, penanggung jawab pasien (perawat) dan keluarga. Keluarga memainkan sebuah peran yang sangat penting dalam menentukan perilaku anggota keluarganya yang sakit, bersifat mendukung selama masa penyembuhan dan pemulihan akan sangat berkurang (Kaplan, 2010). Berdasarkan hasil penelitian di Rumah Sakit Jiwa Daerah Abepura diketahui bahwa dari 30 responden yang dilakukan penelitian sebagian responden merupakan keluarga yang berperan dalam mencegah kekambuhan sebanyak 15 responden $(50.0 \%)$.

Peran dalam keluarga memiliki dua jenis yaitu peran formal dan peran informal, peran formal sendiri merupakan peran yang sudah jelas dan nyata terlihat seperti peran suami-ayah, istriibu, anak, kakak-adik. Ayah sebagai kepala keluarga mencari nafkah, ibu sebagai pengurus rumah tangga dan seterusnya. Berbeda dengan peran formal, peran informal merupakan bentuk peran yang tidak terlihat secara pasti. Peran 
informal adalah peran secara tertutup, bersifat implisit, sering kali tidak tampak pada permukaan, dan diharapkan memenuhi kebutuhan emosional keluarga (Satir, 2012).

Selain itu (Friedman, 2010) untuk memelihara keseimbangan keluarga peran informal keluarga meliputi pendorang, penyelaras, insiator-kontributor, negosiator, penghalang, dominator, penyalahan, pengikut, pencari pengakuan, martir, wajah tanpa ekspresi (great stone face), sahabat, kambing hitam keluarga, pendamai, pengasuh keluarga, pionir keluarga, anggota yang tidak relevan atau distraktor, koordinator keluarga, perantara keluarga dan penonton.

Setiap anggota keluarga memiliki peran dan kedudukannya masimg-masing. Keluarga sebagai sebuah kelompok kecil selalu berkembang berdasarkan pola interaksi yang terjalin di antara anggota keluarga tersebut. Setiap anggota keluarga bebas untuk memerankan dan mengkomunikasikan peran yang sedang disandang olehnya kepada anggota keluarga yang lain. Peran yang disandang, dilaksanakan dalam konteks hubungan interaksi dengan anggota keluarga yang lain dengan sistem aturan yang terorganisasi (Klein, 2010).

Dalam penelitian ini keluarga yang berperan dalam mencegah kekambuhan memberikan perhatian dan kasih sayang kepada pasien skizofrenia dimana sebagian besar adalah kakak/ adik. Perhatian dan kasih sayang tulus dari keluarga dan orang-orang terdekat akan sangat membantu proses peyembuhan kondisi jiwanya (Tarjun, 2014).

Dalam penelitian ini, sebagian responden sebagai kakak atau adik yang mengantar pasien skizofrenia berobat ke rumah sakit. Kakak atau adik merupakan keluarga yang selalu mengantar pasien tersebut termasuk tindakan saat penyakitnya tidak dapat disembuhkan dan diobati, layanan medis dan kesehatan yang dimanfaatkan, serta sumber bantuan keluarga primer, peran prevasif dan inti dari kakak sebagai yang mengantar membuat seorang kakak yang mengambil keputusan kesehatan utama, pendidik, konselor, dan pemberi asuhan dalam matriks keluarga telah menjadi temuan konstan (Finley, 2012).

Selain itu, keluarga mendukung penuh dalam proses pengobatan dan merawat pasien secara langsung, keluarga mengetahui aktivitas yang dilakukan pasien di rumah, keluarga merupakan orang terdekat pasien skizofrenia sebagai keluarga inti, di mana keluarga tersebut terdiri dari ayah, ibu, anak, suami/istri, kakak/adik yang mempunyai hubungan darah yang menimbulkan hubungan secara emosional (Karla, Nischal, et all 2012). Dalam penelitian McDonell (2013) disebutkan bahwa anggota keluarga yang merawat pasien skizofrenia secara otomatis bertanggung jawab kepada pasien skizofrenia. Tanggung jawab itu dapat berupa membiayai perawatan psikiatris, mendampingi, bergelut dengan berbagai stigma yang melekat, serta stres yang terjadi pada keluarga.

Pentingnya peran keluarga dalam upaya kesembuhan pasien dikarenakan keluarga merupakan sistem pendukung utama yang memberikan perawatan langsung pada setiap keadaan sehat dan sakit. Keluarga merupakan unit paling dekat dengan penderita dan merupakan "perawat utama" bagi penderita. Keluarga berperan dalam menentukan cara atau perawatan yang diperlukan penderita di rumah. Keberhasilan perawat di rumah sakit akan sia-sia jika tidak di teruskan di rumah yang kemudian mengakibatkan penderita harus dirawat kembali (kambuh). Peran serta keluarga sejak awal perawatan di rumah sakit akan meningkatkan kemampuan keluarga merawat penderita di rumah sehingga kemungkinan kambuh dapat dicegah (Nasir, 2012).

Aspek-aspek keharmonisan keluarga menurut Stinnets \& De Frain (2014) mengemukakan bahwa sebagai suatu pegangan atau kriteria menuju hubungan perkawinan atau keluarga yang sehat dan bahagia aspeknya adalah menciptakan kehidupan beragam dalam keluarga, mempunyai waktu bersama keluarga yaitu dalam kondisi apapun waktu untuk bersama keluarga harus ada. Suami harus punya waktu untuk istri dan juga sebaliknya, mempunyai komunikasi yang baik antar anggota keluarga, saling menghargai sikap anggota keluarga, saling menghargai prestasi keluarga, mengatasi berbagai macam krisis yang mungkin terjadi dengan cara positif dan konstruksi.

Dilihat dari peran keluarga sebagai penolong, menurut Keliat (2010) dengan keluarga yang bersikap terapeutik dan mendukung pasien, masa kesembuhan pasien dapat dipertahankan selama mungkin. Sebaliknya, jika keluarga kurang mendukung, angka kekambuhan akan menjadi lebih cepat. Hal ini di dukung oleh berbagai 
penelitian mengenai peran keluarga antara lain yang menyatakan bahwa partisipasi keluarga mendorong peningkatan fokus keluarga. Hal ini didukung oleh berbagai penelitian mengenai peran keluarga antara lain Knitzer, Steinbergh \& Fleich (2013) yang menyatakan bahwa partisipasi keluarga mendorong peningkatan fokus keluarga.

Berdasarkan hasil penelitian di Rumah Sakit Jiwa Daerah Abepura diketahui bahwa dari 30 responden yang dilakukan penelitian sebagian responden merupakan keluarga yang tidak berperan dalam mencegah kekambuhan sebanyak 15 responden $(50.0 \%)$. Hal ini sesuai dengan hasil penelitian yang dilakukan oleh Vough \& Snyder dalam Keliat (2010) memperlihatkan bahwa keluarga yang tidak berperan seperti ekspresi emosi yang tinggi (bermusuhan, mengkritik) di perkirakan kambuh dalam waktu sebulan dan kemudian dirawat kembali. Penelitian yang dilakukan di Amerika membuktikan bahwa peranan keluarga yang baik akan mengurangi angka perawatan di rumah sakit, kekambuhan dan memperpanjang waktu antara kekambuhan (Lauriolle, 2015).

Tingginya angka kekambuhan kembali sebanyak 17 orang $(56.7 \%)$ pasien skizofrenia dapat diakibatkan karena keluarga menyudutkan atau menyalahkan penderita skizofrenia, seharusnya keluarga berada di posisi yang mendukung, salah satu caranya adalah dengan ikut merawat (Karla et al, 2012).

Penelitian lain yang dilakukan oleh Sirait (2008) menyatakan bahwa peningkatan angka relaps (kekambuhan) berhubungan secara bermakna dengan emosi yang berlebihan dilingkungan rumah, terutama di dalam rumah yang tidak harmonis, ketidaktahuan keluarga dalam menghadapi penderita dan juga pengobatan yang tidak adekuat yang dilakukan oleh keluarga terhadap penderita.

Oleh karena itu sebagai keluarga diharapkan lebih berperan dalam menurunkan kejadian kekambuhan/ relaps. Dari penelitian juga diketahui keluarga telah mengetahui bahwa pentingnya waktu kontrol, dan minum obat tepat waktu. Namun, sedikit sulit jika berada di rumah karena membutuhkan pengawasan yang terusmenerus membuat keluarga menjadi bosan, selain itu kurangnya informasi atau pengetahuan mengenai perawatan pasien skizofrenia di rumah, dan stigma yang masih melekat pada masyarakat seperti: dikucilkan, tidak dapat berproduktifitas, tidak berguna, menakutkan, dan lain sebagainya.

\section{KESIMPULAN}

Gambaran peran keluarga dalam merawat pasien gangguan jiwa skizofrenia yang mengalami kekambuhan diketahui bahwa dari 30 responden yang diteliti 15 keluarga $(50.0 \%)$ berperan dalam merawat kekambuhan pasien skizofrenia dan 15 keluarga $(50.0 \%)$ tidak berperan dalam merawat kekambuhan pasien skizofrenia.

\section{DAFTAR PUSTAKA}

Amelia. (2013). Dasar-Dasar Keperawatan Jiwa Pengantar dan Teori. Jakarta: Salemba Medika.

Arif, I. S. (2011). Skizofrenia Memahami Dinamika Keluarga Pasien. Bandung: PT Refika Aditama.

Arikunto. (2012). Prosedur Penelitian Suatu Pendekatan Praktik. Jakarta: Rineka Cipta

Azwar. (2013). Sikap Manusia Teori dan pengukurannya. Yogyakarta: Pustaka Pelajar.

Freidman, M. M. (2010). Keperawatan Keluarga Riset, teori dan Praktis. Jakarta: Buku Kedokteran EGC.

Geddes. (2012). Psikologi Kesehatan. Jakarta: PT Raja Grafindo Persada.

Gunarsa, S.D., \& Gunarsa, Y.S., (2001). Psikologi Praktis: Anak, Remaja dan Keluarga. Jakarta: BPK Gunung Mulia, hlm. 77.

Hayati, L., Elita, V., \& Hasanah, O. (2008). Gambaran Pengetahuan Keluarga Tentang Cara Merawat Pasien Halusinasi di Rumah. Jurnal Online Mahasiswa Program Studi Ilmu Keperawatan Universitas Riau, 1(1), 16.

Herz. O., \& Sundeen, S. (2010). Keperawatan Keluarga. Yogyakarta: Graha Ilmu

Isaac. (2010). Keperawatan Kesehatan Jiwa \& Psikiatrik. Jakarta: EGC

Jested., \& Mueser. (2011). Teori dan Pengukuran Pengetahuan, Sikap dan Perilaku Manusia. Yogyakarta: Nuha Medika

Kaplan., \& Sadock. (2010). Buku Ajar Psikiatrik Klinis. Jakarta: EGC

Kazadi, N. J. B. M. Y. H., Moosa., \& Jeenah, F. Y. (2008). Factors Associated with Relapse in Schizophrenia. Johannesburg: Division of Psychiatry, University of the Witwatersrand. Diperoleh dari http://www.ajol.info/index.php/sajpsyc/articl 
Haslinda Manda : Gambaran Peran Keluarga Dalam Merawat Pasien Gangguan Jiwa Skizofrenia Yang Mengalami Kekambuhandi Instalasi Rawat Jalan Rumah Sakit Jiwa Daerah Abepura

e/viewFile/34432/6360. (diakses pada tanggal 29 januari 2017 pukul 12.05).

Keliat. (2012). Keperawatan Jiwa terapi Aktivitas Kelompok. Jakarta: EGC

Knitzer, J., Steinberg, Z., \& Fleisch, B. (2009). At the Schoolhouse Door: An Examination of Programs and Policies for Children with Behavioral and Emotional Problems. New York: Bank stress College of education. (Diakses tanggal 16 Februari 2017 pukul 15.35).

Komalasari, P. P. (2008). Stigma terhadap penderita skizofrenia dalam manga burakku jakku ni yoroshiku karya shuho sato.

Lauriello. (2015). Konsep Dasar Keperawatan Kesehatan Jiwa. Jakarta: EGC

Mayasari, M. D. (2010). Peran Keluarga dalam Proses Rehabilitasi Penderita Skizofrenia. Malang: Universitas Negeri Malang. (Diakses pada tanggal 20 januari 2017 pukul 16.00)

Mubarak.

(2010).

Skizofrenia

http://www.Indonesia.com/f/10629-

skizofrenia. diakses pada tanggal 12 maret 2017.

Mueser, K. T., \& Jeste, D. V. (2011). Clinical Hand Book of Schizophrenia, New York: Guilford.

Notoadmojo. (2012). Metodologi Penelitian Kesehatan. Jakarta: Rineka Cipta

Nursalam. (2012). Konsep dan Penerapan Metodelogi Penelitian Ilmu Keperawatan Pedoman Skripsi, Tesis dan Instrumen Penelitian Keperawatan. Jakarta: Salemba Medika.

Porkony., et al. (2012). Components and Correlates of Family Burden in Schizophrenia. Jurnal Gym. 245-250.

Pratt. (2011). Panduan Belajar : Keperawatan Kesehatan Jiwa \& Psikiatrik. Edisi 3. Jakarta: ECG.

Salomon., et al. (2012). A Phenomenological research design illustrated. International Journal of Qualitative Methods, 3 (1). Article 4. http://www.ualberta.ca/iiqm/backissues/31/pdf/grenewald.pdf. Diakses pada tanggal 15 Maret 2017.

Satir, E. (2012). Peran Dukungan Keluarga dalam Penanganan Penderita Skizofrenia. Skripsi Sarjana Psikologi, Universitas Muhammadiyah Surakarta.
Setiadi. (2011). Konsep dan Proses Keperawatan keluarga. Edisi Pertama: Yogyakarta : Graha Ilmu

Sira, I. (2011). Karakteristik Skizofrenia di Rumah Sakit Khusus Alianyang Pontianak Periode 1 Januari-31 Desember 2009. Jurnal Mahasiswa PSPD FK Universitas Tanjungpura, 2(1).

Stuart., \& Laria. (2011). Keperawatan Jiwa. Edisi 3. Jakarta: Penerbit Buku Kedokteran EGC

Stuart., \& Sundeen. (2011). Keperawatan Jiwa. Edisi 3. Jakarta: Penerbit Buku Kedokteran EGC

Sulingger. (2010). Keperawatan Jiwa Edisi Revisi. Bandung : PT Refika Aditama

Sumarjo. (2010). Faktor Penyebab Kekambuhan Pada gangguan Hibrefenik Pasca dari RSJ. Malang:Universitas Muhammadiyah malang. Diperoleh dari http://eprint.umm.ac.id/3413/ (diakses tanggal 30 Januari 2017 pukul 18.37).

Supartini, Y. (2010). Buku Ajar Konsep dasar keperawatan Anak. Jakarta : EGC

Tomb. (2014) .Buku Saku Diagnosa Keperawatan Pada Keperawatan Psikiatrik. Pedoman Untuk Pembuatan Rencana perawatan Edisi 5, jakarta: EGC

Urizo., \& Maldonado. (2012). Hubungan Persepsi Keluarga Tentang Gangguan Jiwa Dengan Sikap Keluarga Pada Anggota keluarga Yang Mengalami Gangguan Jiwa Di Rumah sakit Jiwa Daerah Surakarta. Naska Publikasi. FIK UMS

Videbeck. (2010). Buku Ajar Keperawatan Jiwa. Jakarta: EGC

Vijay. (2010). Cara Pencegahan dan Pengobatan Penyakit Gangguan Jiwa. Dipublikasikan http://www.balipost.co.id. (diakses pada tanggal 29 januari 2017 pukul 20.07).

Viora. (2010). Pengantar Psikologi Abnormal. Bandung: PT Refika Aditama

Vough. (2012). Terapi modalitas keperawatan Kesehatan Jiwa. Jakarta: EGC 